\title{
Discussion on the Reform of Archives Management System in Colleges and Universities from the Theory of Life Cycle of Records
}

\author{
Xia Chen \\ Shandong Technology and Business University \\ Yantai, Shandong, 264005
}

\begin{abstract}
This paper demonstrates how to realize the integrated management of documents in the real sense by sketching the theory of life cycle of records and the whole process management of documents and archives work in colleges and universities, so as to achieve the efficiency of document management and the minimum operating cost and maximum benefit of the organization management. In view of the problem that the university archives management system seriously restricts the development of archives work, the aspects of the weakening of the archives institution setting, the separation setting of document management and archives management, chaotic and unsystematic archives management and no front-end control and whole process management are analyzed. Finally, the system of archives management in colleges and universities is reformed. The countermeasures of innovating management mechanism, ensuring the hardware facilities and funds of the archives management, strengthening the information construction of university archives, enhancing the service function, improving the work efficiency, strengthening the development of quality and building a new platform for team development are put forward to promote the stable and efficient development of archives work in colleges and universities.
\end{abstract}

Keywords-Colleges and universities; The theory of life cycle of records; Archives; Management; System

I. A Brief Description of the Life CyCle TheORy OF Records and THe Whole Process Management of DOCUMENTS AND ARCHIVES IN COLLEGES AND UNIVERSITIES

The theory of life cycle of records is a theory which was introduced from the West in the mid and late 1980s on the basis of the generalized document view. It was first proposed by American archivists Philip Brooks in 1940. This theory looks at the entire movement process of documents from generation to conversion to archives, with the view of universal contact and movement development. It believes that the document from its formation to destruction or permanent preservation is a complete movement process, and the documents and archives are different stages of the same thing, and then regards the management and disposal of document to the archives as a process of cohesion and close connection, and it also believes that a unified management system and working process should be adopted so as to fully monitor and manage the whole life process of the documents[1]. That is to say, the existing documents management and archives management can't be regarded as two stages which are independent and irrelevant. Instead, the two systems should be managed coherently and comprehensively from organization system, management mode to working procedure in order to achieve the integrated management of documents and archives in a real sense and realize the efficient management of documents, so as to ensure the minimum operation cost and maximum benefit of the institution management[12].

University documents and archives management is a systematic project involving all sectors of the school. The formation and accumulation of university documents and archives is inseparable from the management and business activities of universities. The quality of documents and archives in colleges and universities that is the authenticity, integrity and system effectiveness of archive materials depends on the standard and order of the management and business activities. In order to ensure the quality of work of documents and archives, the management of university documents and archives must be integrated into their management and business activities to form an organic whole of the whole process management and monitoring, so that the archival work can truly enter a healthy development track. The standardized management of documents and archives in colleges and universities will promote the standardization and institutionalization of management activities and business activities, so as to further improve the management level of the whole university, and promote the continuous and stable development of education[3].

The whole process management of the documents and archives work of the university should cover the whole process from a variety of office systems, software design, maintenance and the formation or operation of a document to the conversion of documents to archives and the preservation and disposal of archives, and includes all aspects of document management, archive management and business management. The author thinks that the meaning of the whole process management of the university documents and archives is that the current documents and archives management should be effectively connected and integrated into the management and business links of colleges and universities to achieve a comprehensive reform from the management system, the organization to the work system, the working process and the technical method, thus realizing a systematic project of full control and management of the whole document(including the current documents and archives) movement process[4]. 
II. The Archives Management System in Colleges AND Universities SerIOUSLy Restricts the DeVELOPMENT OF ARCHIVES WORK IN COLLEGES AND UNIVERSITIES

With the development of modern science and technology especially the development of network information technology and media technology, and with the reform and rapid development of the colleges and universities, the original archives management system is becoming more and more difficult to meet the needs of the development of the archives work under the new situation. There are disadvantages in the archives management system, which leads to the failure of the archives department to achieve effective front-end control and whole process management.

The institutional setting can't reflect its functional characteristics, and it weakens the administrative power of the archives department[5]. The archival law stipulates the dual functions of archives institutions in colleges and universities. One is to centrally and uniformly manage the archives keeping function of the whole school archives, and the other is the right of administrative management, that is to supervise and direct the school's archival work, including checking, examining and supervising the archives work of the whole school. However, archives institutions in colleges and universities are usually set up in the archives (room). The application of the institution cannot reflect its administrative power. The power that archives laws and regulations entrust to university archives departments are not authorized or recognized in reality, and their administrative power is easily ignored or despised. In fact, the archives department has only the obligations (duties) prescribed by the state and has no administrative power, therefore, the implementation of front-end control and whole process management is very difficult, which seriously dampens the enthusiasm of the archival staff and is not conducive to the smooth development of university archives work under the network environment. The institutional setup mode came from the reform of archives management system in China in 1993. The bureau and archives are integrated into one, that is, the State Archives Bureau and National Archives are merged together. It is the public institution, and an institution has two signs and two functions[6]. The integration of the bureau and archive leads to no distinction between administrative units and institutions. In fact, it has been proved that the unification of the offices is not conducive to the development of the state archives, for example, in the early stages of the development of the French national archives, the national archives also had dual functions of archival keeping and business guidance, but later, this kind of function could not adapt to the development of French archives, so the State Archives Bureau was set up, which was fully responsible for the supervision and guidance function of archival business. The national archives had become the institutions that simply keep the national archives. A system of two functions does not conform to our Party on the principle of the reform of the administrative system of separating administrative units and institutions, separating enterprise from government, separating the government regulation from management[7].

The documents management and the archives management belong to the separate and independent management system of the two institutions. First, the paperwork is divorced from the archives work. The document processing department and archival department manage their own operations in different modes within their respective systems, and the document processing is out of touch with archival management. Second, the business management is divorced from the archive management. The two are operated by different personnel in different management modes in different institutions, and they lacks contact and communication, which results in that the archival departments can't perform the functions of supervision and guidance for document management, let alone front-end control and whole process monitoring and management. The business department attaches great importance to internal management, but ignores external cooperation and ignores or avoids the proper management and filing of documents. There is a lack of a unified document management system and workflow. It is difficult to effectively monitor the filing documents quality from the source and it is difficult to effectively reflect the full picture of the work.

The archives work does not realize the centralized management of real significance. Although the archives managed by the university archives are comprehensive files, many school cadres, personnel archives, and students' archives(undergraduate archives and postgraduate archives) are still in the state of decentralized management by the relevant departments. If there are several archives in a school, the personnel will work in their own way, and the management system and methods will be disorganized, which will cause repeated construction and waste of resources and the archival resources can't be effectively shared and utilized.

The business process in the manual work environment needs to be built or reorganized. Although the archives department of colleges and universities use computers and networks, it is only an auxiliary management of the archives. In fact, it is a simple imitation of the manual work process of paper archives. Most of the archives are not integrated into the management and business activities of colleges and universities, and it is difficult to implement effective front-end control and whole process management. The archives business process of colleges and universities under the network environment needs to be reorganized or constructed[8].

\section{ANALYSIS OF THE REASONS FOR RESTRICTING THE}

\section{REFORM OF ARCHIVES IN COLLEGES AND UNIVERSITIES}

The section and office should be separated, the archive division and archives should be separated, and the archives section or archives division should be established. For the system of no separation between the administrative units and institutions that is the combination of archive bureau and archives, some scholars have proposed "the implementation of the separation of the archive bureau and archives, and the separation of the administrative units and institutions to strengthen the respective functions of the archive bureau and archives, and optimize the management system of the archives in China"[1]. In view of this, the author suggests that colleges and universities can take this way to separate the second and office, separate archive division and archives, and set up independent archives section or archives division. Two independent institutions and two sets of personnel can fulfill their respective functions of archival preservation and 
administrative management. This will greatly enhance the enthusiasm of archivists and the vitality of archives organizations, make document management and archives work more smoothly, and greatly promote the development of archives cause in colleges and universities. The reform of the archives institutions is an important part of the reform of the archives management system in colleges and universities.

As for the problem of independent operation of document management and archives management, some scholars have proposed that "there are many drawbacks in the separate management of documents and archives, which are not conducive to the integrated management of documents, nor to the implementation of front-end control for electronic files. Therefore, we should change our current archival management system. It is best to "declare and stipulate in a clear way that the State Archives Bureau is the institution that governs documents and archives affairs, or even renamed the National Documents and Archives Bureau".

The author believes that the function of document management and archive management should be integrated. The specific approach is to transfer the paperwork of the Party Committee Office and School Office to the archives department, and meanwhile, integrate the document management of various departments in the whole school. The superior documents received by the functional departments and the issued red-head documents should be also managed by the archives departments. We should straighten out the relationship between the two links of document management and archives management fundamentally, establish the integrated management system of documents and archives, and realize the idea of front-end control and whole process management advocated by the file management life cycle, so that the two can integrate with each other and the ideal integrated management of documents in the eyes of archivists can be truly realized.

The archives of the internal departments of colleges and universities, such as the archives of the personnel department, educational administration department and student office, should be merged into the school archives department to achieve the centralized and unified management of archives, and realize the expansion of the functions of archives, including the inclusion of school history museum, museum and compilation work.

The internal organization and business processes should be reorganized. The archives department should actively participate in the planning and construction of the school information, study and solve the archives management system and compatibility and connection of office business systems, actively integrate the university management and business activities, and use technical means to embed front-end control and whole process management into the related business system, and meanwhile, actively carry out the business process reengineering according to the management purpose and the development of the archival work under the network environment and realize the reorganization of the internal organization on this basis, establish and improve the school oriented rules and regulations and business processes, straighten out working relations, and fundamentally improve the effectiveness of document management and archives management and business management.

\section{COUNTERMEASURES AND SUGGESTIONS FOR THE} REFORM OF ARCHIVES WORK IN COLLEGES AND UNIVERSITIES

\section{A. The Innovation of Management Mechanism}

Firstly, the university must establish and improve the archives management mechanism as soon as possible, incorporate archives management into the long-term planning to further improve the equipment and facilities of the archives department, achieve the modernization management by using the high-tech means, and make the development plan of archives information to speed up the management of archives information. Secondly, it is imminent to establish a flexible training mechanism for talents. As the college with high knowledge and high cultural quality, the traditional convention must be first broken, and the bad style of arranging in order of seniority should be also broken to create a fair, equitable and harmonious innovation platform and working environment for the archival staff, so as to mobilize the enthusiasm and creativity of the vast number of archival staff, which will be beneficial to the development and utilization of archival work. Thirdly, colleges and universities can establish corresponding performance assessment, in order to establish a good incentive mechanism, so that the talent competition can enter the ecological atmosphere, and the talents will stand out. Fourthly, the typical example should be set up to mobilize the enthusiasm of archival staff, fully promote the development of archival staff, and promote the overall level of archival work. Fifthly, it is necessary to do a confidential work in the process of archival keeping, and make sure that the archives do not be destroyed, dirty, lost, dispersed and disordered. The archives should be kept carefully. For inspection, destruction and other links, they should be handled strictly according to the regulations, and after the use of archives, they should be timely checked. At the same time, we should make full use of the existing resources, strengthen the sharing and utilization of archives resources between universities, between universities and society, and jointly create more value-added services for the development of society and universities.

\section{B. The Hardware Facilities and Funds of Archival Management must be Guaranteed}

Just so-called “one can't make bricks without straw”, the same is true for archives management department. As we all know, the development and utilization of archives utilization rate can't do without the support of hardware, and it is inseparable from the support of information technology, which requires a certain amount of funds as backing. Therefore, colleges and universities can set up special funds in this respect. Of course, under sufficient funds, we should also pay attention to the cost problem, so as not to cause waste.

\section{Strengthening the Information Construction of Archives in Colleges and Universities}

The informatization construction of university archives is a part of information construction in colleges and universities. Therefore, we should try our best to do more efforts and 
construction in this area to cope with the rapidly developing information-based society.

\section{Strengthening Service Function and improving Work Efficiency}

The weak service consciousness is a common problem existing in the current archives management staff. Therefore, colleges and universities must work hard in this regard, firmly establish the service awareness of archival management staff, strengthen service functions, vigorously innovate service means, change passive service to active service, and realize the document resource sharing with the latest science and technology. Meanwhile, colleges and universities should also actively explore new areas of archives, innovate continuously, improve their work quality, make good bridge between archives and archival users, realize the transformation of static archives into dynamic information, and continuously improve the development capacity of archival information resources.

\section{E. Strengthening the Quality Development and building a New Platform for the Team Development}

As we all know, the smooth development of the archival work and the future development of the archival work depend on the quality of the archival staff. Therefore, it is one of the most important works to strengthen the quality expansion of the archival staff and train the loyalty of the archival staff. Colleges and universities must make more efforts in this regard, and cultivate excellent personnel with good business, reasonable structure and loyalty to the archives for the archives department of colleges and universities.

\section{REFERENCES}

[1] Renjie Ma and Hao Zhang: Some Thoughts and Suggestions on Improving the Management System of Chinese Archives[J], Archives Science Bulletin, 2009, (6). (In Chinese)

[2] Maoyue Wang: Rethinking on the Concept of Large Documents[J], Archives management, 2009, (1). (In Chinese)

[3] Zehu Zhao: Standardize the Management System of Colleges and Universities to Improve the Level of Archival Work[J], Lantai World: first half of the month, 2007,(11). (In Chinese)

[4] Ming Fan: Thinking on the Construction of Large Archives Management System in Colleges and Universities[J], China Archives, 2009, (12). (In Chinese)

[5] Yanping Tan: The Reform Process and Development Trend of the Archives Management System in China's Colleges and Universities[J], Lantai World: the middle ten days of a month, 2012, (8). (In Chinese)

[6] Xia Chen: On the Reengineering of the File Business Process under the Network Environment[J], Lantai World: first half of the month, 2005, (1). (In Chinese)

[7] Desheng Lai and Changan Li: The Main Contradictions and Countermeasures in the Field of Employment in China[J], Economics Information, 2010(3). (In Chinese)

[8] Jifu Wang and Enli Luo: Western Employment Theory and Practice and Its Enlightenment to China[J], Journal of Xi'an Jiaotong University (Philosophy and Social Sciences), 2000(12). (In Chinese) 